\title{
INOVASI PEMBELAJARAN PAI DI SEKOLAH PADA ERA DISRUPTIVE INNOVATION
}

\author{
Tedi Priatna 1 \\ 1Yayasan Amal Bakti Gombong Layang Cipadung 1, Bandung, Indonesia \\ 1emai: tedipriatna2018@gmail.com
}

\begin{abstract}
Abstrak
Fokus utama naskah ini adalah gagasan inovatif pembelajaran PAI di sekolah menghadapi disruptive innovation era digital. Pembahasan menggunakan analitis kritis sebagai pengembangan dari metode deskriptif. Objek kajian adalah gagasan atau ide. Teknik pengumpulan data yang digunakan adalah book survey atau library research. Hasil pembahasan menunjukkan: (1) Model pembelajaran adalah kerangka konsep-tual yang menggambarkan prosedur sistematis dalam mengorganisasikan pengalaman untuk mencapai tujuan belajar. Model pembelajaran terbentuk dari unsur fokus, sintaks, sistem sosial dan situasi pembelajaran, serta faktor pendukung; (2) Pembelajaran PAI merupakan upaya mendorong peserta didik untuk mempelajari kurikulum PAI yang mengakibatkan perubahan tetap dalam tingkah laku peserta didik. Upaya mengoptimalisasi pembelajaran PAI di sekolah menghadapi Disruptive innovation, diantaranya: Pertama, Diperlukan perubahan paradigma pembelajaran PAI yang bukan hanya terbatas pada orientasi kognitif semata, tapi juga ranah psikomotor, afeksi dan aspek sikap serta prilaku keberagamaan. Kedua, Pembelajaran PAI di sekolah/madrasah harus dikembangkan dan diinovasi sedemikian rupa, sehingga pembelajaran PAI menjadi up to date dan menarik minat para siswa. Penggunaan teknologi informasi dalam model pembelajaran PAI harus terus dikembangkan dan ditempatkan sebagai sumber, referensi, dan informasi bahan ajar. Penggunaan media sosial dalam pembelajaran juga harus menjadi alternatif. Termasuk digunakan dan dimanfaatkannya media sosial untuk pengembangan pembelajaran PAI di sekolah.
\end{abstract}

Kata kunci: Inovasi Disruptif, Era Digital, Model Pembelajaran PAI;

\section{Abstract}

The main focus of this paper is the innovative idea of Islamic Education learning in schools facing the disruptive innovation of the digital age. The discussion uses critical analytics as part of the development of descriptive methods. The object of study is ideas. Data collection techniques used are book survey or library research. The results of the discussion show several important findings. (1) Learning model is a conceptual framework that describes the systematic procedure in organizing experiences to achieve learning objectives. The learning model is formed from the element of focus, syntax, social system and learning situation, and supporting factor. (2) Learning Islamic Education is an effort to encourage learners to earn the curriculum of Islamic Education which resulted in a change 
Priatna, T. (2018, July 9). INOVASI PEMBELAJARAN PAI DI SEKOLAH PADA ERA DISRUPTIVE INNOVATION. Jurnal Tatsqif, 16(1), 16-41. Retrieved from http://journal.uinmataram.ac.id/index.php/tatsqif/article/view/158

in the behavior of learners. There are efforts to be taken to optimize the learning of Islamic Education in schools facing disruptive innovation. First, there is a need to change the paradigm of learning Islamic Education not only limited to cognitive orientation, but also psychomotor domain, affection, and attitude aspects as well as religious behavior. Second, Islamic Education learning in schools/madrasah should be developed and innovated in such a way that Islamic Education learning is up-to-date and attracts students' interest. The use of information technology in the Islamic Education learning model should continue to be developed and placed as a source, reference, and information resource. The use of social media in learning should also be an alternative, including the use and utilization of social media for the development of Islamic Education learning in schools.

Keywords: Disruptive Innovation; Digital Era; Islamic Education Learning Model;

\section{PENDAHULUAN}

Dunia saat ini memasuki era revolusi industri 4.0, yang ditandai dengan masifnya perkembangan pola digital economy, artificial intelligence, big data, robotic, dan yang paling mengagetkan adalah fenomena disruptive innovation. Selama beberapa dekade terakhir dunia berubah jauh lebih cepat. Disruptive innovation menghadirkan banyak sekali inovasi, tidak disadari oleh organisasi mapan tapi dirasakan mengganggu aktivitas tatanan sistem yang lama. Disruptive innovation sangat potensial menghancurkan sistem yang sudah berjalan. Dan hal tersebut semata didorong oleh perkembangan teknologi informasi yang begitu cepat. Toko-toko retail yang mulai gulung tikar karena hadirnya e-commerce, taksi konvensional yang kehilangan sebagian besar pendapatannya karena hadirnya layanan transportasi online, adalah daftar sederhana korban lahirnya disruptive innovation ini.

Fenomena disruption innovation sudah banyak dibahas di sektor ekonomi, perbankan, pariwisata, dan lain sebagainya. Namun, masih terbatas dibahas di sektor pendidikan. Sementara itu, di luar sudah banyak sekali institusi pendidikan yang terus bergerak lincah. Bukan hanya universitas swasta, tapi universitas - universitas online. Dan yang paling harus dicermati 
Priatna, T. (2018, July 9). INOVASI PEMBELAJARAN PAI DI SEKOLAH PADA ERA DISRUPTIVE INNOVATION. Jurnal Tatsqif, 16(1), 16-41. Retrieved from http://journal.uinmataram.ac.id/index.php/tatsqif/article/view/158

adalah fenomena disruption innovation ini juga merambah dan potensial berdampak pada anak-anak kita, peserta didik sekolah konvensional.

Perkembangan teknologi informasi dan komunikasi telah membawa perubahan besar dalam berbagai bidang kehidupan, tidak terkecuali dalam dunia pendidikan. Amatan sederhana menggambarkan dinamika prilaku dan kecenderungan peminatan generasi milenial ini saat berinteraksi dengan dunia internet dalam kaitannya dengan dunia pendidikan. Mereka lebih menyenangi informasi berbasis visual (melalui YouTube, online games) ketimbang melalui narasi dan teks-teks (membaca buku cetak atau mendengar ceramah guru). Mereka piawai berselancar dan bereksplorasi di dunia maya, menerima dan mengkurasi informasi ketimbang pasif terperangkap di perpustakaan konvensional. Mereka lebih nyaman untuk belajar secara kolaboratif di dalam praktik nyata atau secara peer to peer melalui jejaring sosial (menggunakan social learning platform). Dan mereka lebih suka menggunakan interactive gaming (gamifikasi), ketimbang malas-malasan mengerjakan tugas sekolah.

Ketika anak sekolah kita sudah berubah sedemikian rupa, maka sepertinya tinggal menunggu waktu pendidikan juga akan terkena dampak disrupsi yang merugikan anak-anak kita. Teramat banyak berita dan informasi yang menjelaskan bahwa social learning platform memang memberikan banyak manfaat, tak hanya menjadi media untuk berkomunikasi namun juga menjadi sarana untuk mendapatkan beragam informasi terbaru dan terupdate. Namun, kebermanfaatan tersebut juga sejalan dengan dampak negatif pengiringnya. Fenomena-fenomena tersebut menarik untuk dibicarakan.

Perkembangan teknologi dan informasi nyata sudah tidak bisa dihindari, lalu bagaimana pendidikan merespon dan mengantisipasi hal tersebut? Apatah lagi kalau kita memetakan dampak kemajuan teknologi dan informasi terhadap sikap, kepribadian dan prilaku anak-anak kita. Lebih khusus, terhadap moralitas, karakter, dan keberagamaan anak-anak kita yang selama 
Priatna, T. (2018, July 9). INOVASI PEMBELAJARAN PAI DI SEKOLAH PADA ERA DISRUPTIVE INNOVATION. Jurnal Tatsqif, 16(1), 16-41. Retrieved from http://journal.uinmataram.ac.id/index.php/tatsqif/article/view/158

ini salah satunya merupakan tanggung jawab pembelajaran Pendidikan Agama Islam.

\section{METODE}

Secara metodologis, paparan kertas kerja ini akan menggunakan metode "analitis kritis". Metode ini merupakan pengembangan dari metode deskriptif, yakni mendeskripsi-kan gagasan manusia tentang objek tertentu. Objek kajian dalam metode ini adalah gagasan atau ide manusia yang terungkap dalam bentuk media cetak, baik berupa naskah primer atau naskah sekunder [sumber data primer dan sumber data sekunder]. Gagasan dalam naskah primer adalah sejumlah data mengenai masalah pokok, sedangkan gagasan sekunder adalah pembahasan dan kritik terhadap gagasan primer.

Tujuan analitis kritis adalah mengkaji gagasan primer mengenai suatu "ruang lingkup permasalahan" yang dipercaya sebagai fokus penelitian. Adapun fokusnya adalah (a) mendeskripsikan, (b) membahas, dan (c) mengkritik gagasan primer dan selanjutnya (d) melakukan studi analitik dengan mengembangkan studi yang berupa perbandingan, hubungan, pengembangan model rasional (Surasumantri, 1998). Teknik pengumpulan data yang digunakan adalah book survey atau library research.

Kertas kerja ini secara sistimatis akan mencoba mendeskripsikan bagaimana tantangan yang dihadapi Pendidikan khususnya pembelajaran PAI di era digital. Diawali dengan pembahasaan mengenai model pembelajaran PAI, tantangan pembelajaran PAI di era digital, dan diakhir akan disodorkan alternatif gagasan-gagasan inovatif tentang pembelajaran PAI di sekolah

\section{HASIL DAN PEMBAHASAN}

\section{A. MODEL PEMBELAJARAN}

Pembelajaran (instruction) merupakan upaya untuk membelajarkan seseorang atau kelompok melalui metode, dan strategi ke arah tujuan yang telah direncanakan. Pembelajaran dipandang sebagai 
Priatna, T. (2018, July 9). INOVASI PEMBELAJARAN PAI DI SEKOLAH PADA ERA DISRUPTIVE INNOVATION. Jurnal Tatsqif, 16(1), 16-41. Retrieved from http://journal.uinmataram.ac.id/index.php/tatsqif/article/view/158

kegiatan guru dalam desain instruksional untuk memfasiitasi siswa belajar. Pembelajaran menurut Oemar Hamalik adalah suatu kombinasi yang tersusun, meliputi unsur-unsur manusiawi, fasilitas, perlengkapan dan prosedur yang saling mempengaruhi untuk mencapai tujuan pembelajaran (Hamalik, 2011). Pembelajaran merupakan kegiatan yang direncanakan untuk mengkondisikan seseorang agar bisa belajar dengan baik sesuai dengan tujuan pembelajaran. Kegiatan pembelajaran bertumpu pada 2 (dua) proses utama: pertama, bagaimana orang melakukan perubahan tingkah laku melalui kegiatan belajar. Kedua, bagaimana orang melakukan penyampaian ilmu pengetahuan melalui pembelajaran (Majid, 2012).

Dalam praktiknya, pembelajaran dikembangkan berdasarkan model-model tertentu. Model dimaknakan sebagai suatu objek atau konsep yang digunakan untuk merepresen-tasikan sesuatu hal; Sesuatu yang nyata dan dikonversi untuk sebuah bentuk yang lebih komprehensif (Trianto, 2012). Secara umum istilah model diartikan sebagai kerangka konseptual yang digunakan sebagai pedoman dalam melakukan suatu kegiatan. Model juga diartikan sebagai barang atau benda tiruan dari benda yang sesungguhnya (Jaskati, 2005).

Lalu apa yang dimaksud dengan model pembelajaran? Gunter mendefinisikannya sebagai an instructional model is a step-by-step procedure that leads to specific learning outcomes. Joyce dan Weil memberikan definisi model pembelajaran sebagai kerangka konseptual sebagai pedoman dalam melakukan pembelajaran (Joyce, Weil, \& Calhoun, 2011). Model pembelajaran merupakan kerangka konseptual yang menggambarkan prosedur yang sistematis dalam mengorganisasikan pengalaman belajar mencapai tujuan belajar.

Jika diamati secara mendalam, model pembelajaran sesungguhnya merupakan proses yang kompleks, yang dapat diterjemahkan sebagai penggunaan secara integrative sejumlah komponen yang terkandung 
Priatna, T. (2018, July 9). INOVASI PEMBELAJARAN PAI DI SEKOLAH PADA ERA DISRUPTIVE INNOVATION. Jurnal Tatsqif, 16(1), 16-41. Retrieved from http://journal.uinmataram.ac.id/index.php/tatsqif/article/view/158

dalam perbuatan untuk menyampaikan pesan pengajaran. Model pembelajaran tidak bisa lagi dimaknai sebagai usaha penyampaian dan penyerahan pengetahuan semata, tapi lebih dari itu. Conner sebagaimana dikutif dari J.J. Hasibuan \& Moedjiono (1986) memberikan ilustrasi melalui analisis substansi tugas mengajar guru menjadi tiga tahap suksesif, yakni: tahap sebelum pengajaran (Pre-active), tahap pengajaran (inter-active), dan tahap sesudah pengajaran (post-active).

\begin{tabular}{|c|c|c|c|}
\hline & \multicolumn{3}{|c|}{ TUGAS GURU } \\
\hline & $\begin{array}{l}\text { Tahap Sebelum } \\
\text { Pengajaran (pre- } \\
\text { active) }\end{array}$ & $\begin{array}{l}\text { Tahap Pengajaran } \\
\text { (Interactive) }\end{array}$ & $\begin{array}{l}\text { Tahap Sesudah } \\
\text { Pengajaran (Post } \\
\text { active) }\end{array}$ \\
\hline & $\begin{array}{l}\text { Perencanaan: } \\
\text { Tahunan, semester, } \\
\text { catur wulan, unit, } \\
\text { satuan pelajaran }\end{array}$ & $\begin{array}{l}\text { Pengelolaan } \\
\text { Kontrol } \\
\text { Penyampaian } \\
\text { informasi } \\
\text { Penggunaan } \\
\text { tingkah laku verbal } \\
\text { dan non verbal }\end{array}$ & $\begin{array}{l}\text { Menilai kemajuan } \\
\text { siswa } \\
\text { Merencanakan } \\
\text { kegiatan } \\
\text { Menilai proses } \\
\text { belajar mengajar }\end{array}$ \\
\hline $\begin{array}{l}\text { FAKTOR } \\
\text { LINGKUNGAN }\end{array}$ & $\begin{array}{l}\text { Bekal bawaan siswa } \\
\text { Perumusan tujuan } \\
\text { Pemilihan metode } \\
\text { Pengalaman belajar } \\
\text { Bahan peralatan }\end{array}$ & $\begin{array}{l}\text { Balikan } \\
\text { Penerapan prinsip } \\
\text { Psikologis }\end{array}$ & $\longrightarrow$ \\
\hline $\begin{array}{l}\text { Ciri masyarakat } \\
\text { Ciri sekolah } \\
\text { Ciri siswa } \\
\text { Kebijakan } \\
\text { pemerintah }\end{array}$ & $\begin{array}{l}\text { Mempertimbangkan: } \\
\text { Ciri-ciri siswa, } \\
\text { langkah pengajaran, } \\
\text { Pola pengelompokan }\end{array}$ & $\begin{array}{l}\text { Mendiagnosis } \\
\text { Kesulitan belajar } \\
\text { Pelayanan } \\
\text { perbedaan } \\
\text { individual }\end{array}$ & $\begin{array}{l}\text { Hasil belajar siswa } \\
\text { Kognitif } \\
\text { Afektif }\end{array}$ \\
\hline Sumber penunjang & Prinsip belajar & Evaluasi & Psikomotor \\
\hline
\end{tabular}

\section{TINGKAH LAKU GURU}

Bagan 1: Analisis Model Pembelajaran menurut R.D. Conners

Soekamto mendefiniskan model pembelajaran sebagai kerangka konseptual yang menggambarkan prosedur sistematis dalam 
Priatna, T. (2018, July 9). INOVASI PEMBELAJARAN PAI DI SEKOLAH PADA ERA DISRUPTIVE INNOVATION. Jurnal Tatsqif, 16(1), 16-41. Retrieved from http://journal.uinmataram.ac.id/index.php/tatsqif/article/view/158

pengorganisasian pengalaman belajar untuk mencapai tujuan belajar. Model berfungsi sebagai pedoman bagi para perancang pembelajaran dan guru dalam merencanakan aktivitas pembelajaran.” Dengan demikian, aktivitas pembelajaran benar-benar merupakan kegiatan bertujuan yang tertata sistematis. Eggen dan Kauchak senada mengemukakan bahwa model pembelajaran adalah kerangka dan arah bagi guru untuk mengajar (Trianto, 2012). Arends (1997) menyatakan, "The term teaching model refers to a particular approach to instruction that includes its goals, syntax, environment, and management system."

Istilah model pembelajaran mengarah pada suatu pendekatan pembelajaran meliputi tujuan, sintaks, lingkungan, dan sistem pengelolaannya (Trianto, 2012). Menurut Abdul Aziz Wahab (2007) dan Dahlan (1990) yang mengadaptasi pendapat Bruce Joyce dan Marsha Weil, model pembelajaran terbentuk melalui berbagai kombinasi dari unsurunsur atau komponen yang meliputi fokus, sintaks, sistem sosial dan situasi pembelajaran, serta faktor pendukung.

a. Fokus. Fokus merupakan aspek sentral dari sebuah sistem. Fokus merujuk pada kerangka acuan yang mendasari sebuah model. Tujuan pembelajaran dan aspek lingkungan membentuk fokus dari model.

b. Sintaks. Sintaks atau tahapan dari model mengandung uraian tentang kegiatan-kegiatan yang disusun berdasarkan tahapan dari keseluruhan program. Sintaks melambangkan prosedur pembelajaran dari setiap model. Sintaks juga merupakan susunan dari keseluruhan pembelajaran.

c. Sistem sosial. Pembelajaran pada dasarnya menggambarkan hubungan antara guru dengan siswa. Elemen ketiga dari model pembelajaran mengarah pada bentuk hubungan yang menjelaskan peranan guru dan siswa, juga menjelaskan hubungan hirarkis dan hubungan kewenangan, serta norma-norma atau perilaku pembelajaran yang dianggap baik. Sistem sosial merupakan bagian 
Priatna, T. (2018, July 9). INOVASI PEMBELAJARAN PAI DI SEKOLAH PADA ERA DISRUPTIVE INNOVATION. Jurnal Tatsqif, 16(1), 16-41. Retrieved from http://journal.uinmataram.ac.id/index.php/tatsqif/article/view/158

penting dari setiap model. Model pembelajaran menjelaskan sistem untuk mengajarkan sikap, keterampilan serta pengertian, dan lain-lain sebagainya.

d. Sistem pendukung. Unsur yang utama dari suatu model adalah elemen pendukung yang tujuannya adalah menyiapkan kemudahan penerapan model pembelajaran.

\section{B. PEMBELAJARAN PAI}

Pembelajaran Pendidikan Agama Islam adalah upaya mendorong peserta didik belajar dan tertarik terus-menerus mempelajari Agama Islam, baik untuk mengetahui bagaimana cara beragama maupun mempelajari Islam pengetahuan (Muhaimin, 2004). Pembelajaran Pendidikan Agama Islam merupakan bimbingan sistematis menjadi pribadi yang tangguh dan mampu merealisasikan ajaran Islam dalam kehidupan sehari-hari sehingga menjadi insan kamil. Penanaman Pembelajaran PAI sangat penting dalam membentuk dan mendasari peserta didik. Dengan penanaman pembelajaran PAI diharapkan mampu membentuk pribadi yang kokoh, kuat dan mandiri dengan berpedoman pada agama Islam. Pembelajaran PAI merupakan kebutuhan peserta didik secara menyeluruh yang diharapkan dapat memberikan perubahan yang tetap, baik dalam kognitif, afektif dan psikomotorik.

Pembelajaran Pendidikan Agama Islam memiliki karakteristik yang berkaitan erat dengan satuan pendidikan dan tentunya dengan Standar Kompetensi Lulusan dan Standar Isi. Sasaran pembelajaran PAI meliputi pengembangan sikap, pengetahuan, dan keterampilan yang dielaborasi secara spesifik sesuai setiap satuan pendidikan tertentu. Ketiga ranah kompetensi tersebut (sikap, pengetahuan, dan keterampilan) memiliki lintasan perolehan psikologis yang beragam. Sikap diperoleh melalui aktivitas menerima, menjalankan, menghargai, dan mengamalkan. Pengetahuan diperoleh melalui aktivitas memahami, menerapkan, 
menganalisis, dan mengevaluasi. Keterampilan diperoleh melalui aktivitas mengamati, mencoba, menyaji, dan mencipta. Karakteristik kompetensi beserta perbedaan lintasan perolehan turut serta mempengaruhi karakteristik standar proses.

Berdasarkan komponen kunci dari model pembelajaran yang diajukan Bruce Joyce dan Marsha Weil, dapat diidentifikasi beberapa hal mengenai model pembelajaran Pendidikan Agama Islam di sekolah/Madrasah.

Fokus Pembelajaran Pendidikan Agama Islam adalah menumbuhkan dan meningkatkan keimanan melalui pemberian pengetahuan, pemupukan, penghayatan, dan pengalaman peserta didik tentang agama Islam, sehingga menjadi muslim yang terus berkembang dalam hal keimanan, ketakwaannya, berbangsa dan bernegara (Majid, 2012).

Adapun fungsi pembelajaran Pendidikan Agama Islam di sekolah/madrasah adalah sebagai berikut:

a. Pengembangan, yaitu meningkatkan keimanan dan ketakwaan peserta didik kepada Allah Swt. yang telah ditanamkan awal dalam lingkungan keluarga. Pada dasarnya dan pertama-tama kewajiban menanamkan keimanan dan ketakwaan adalah orang tua melalui institusi keluarga. Sekolah berfungsi untuk menumbuh-kembangkan lebih lanjut melalui bimbingan, pembelajaran, dan pelatihan agar berkembang optimal sesuai dengan tingkat perkembangannya.

b. Penanaman nilai sebagai way of life dalam rangka mencapai kebahagiaan hidup di dunia dan akhirat.

c. Penyesuaian mental, yakni menyesuaikan diri dengan lingkungannya sesuai dengan ajaran agama Islam.

d. Perbaikan, yaitu untuk mengevalausi kesalahan, kekurangan, dan kelemahan peserta didik dalam keyakinan, pemahaman, dan pengalaman ajaran Islam.

e. Pencegahan, yaitu untuk menangkal hal-hal negatif dari lingkungan 
Priatna, T. (2018, July 9). INOVASI PEMBELAJARAN PAI DI SEKOLAH PADA ERA DISRUPTIVE INNOVATION. Jurnal Tatsqif, 16(1), 16-41. Retrieved from http://journal.uinmataram.ac.id/index.php/tatsqif/article/view/158

atau dari budaya sekitarnya;

f. Pengajaran tentang islam sebagai pengetahuan;

g. Penyaluran, yaitu untuk menyalurkan anak-anak yang memiliki bakat khusus di bidang Agama Islam agar dapat berkembang sehingga bermanfaat untuk dirinya sendiri dan bagi orang lain.

Lingkup pembelajaran pendidikan agama Islam memiliki cakupan luas, karena Islam sebagai ajaran memuat hal ihwal tata hidup yang meliputi seluruh aspek kehidupan manusia, maka pembelajaran Pendidikan Agama Islam merupakan pembelajaran tata hidup berisi pedoman pokok yang digunakan oleh manusia dalam menjalani kehidupannya di dunia ini dan untuk menyiapkan kehidupannya yang sejahtera di akhirat nanti.

Secara prosedural pembelajaran Pendidikan Agama Islam dapat dikembangkan dengan menggunakan prinsip pendidikan Islam yang bersumber dari al-Qur'an dan Hadits. Implikasi metodologis pendidikan dalam al-Qur'an dan Hadits tersebut, di antaranya adalah sebagai berikut :

a. Mendorong manusia untuk menggunakan akal pikirannya dalam menelaan dan mempelajari gejala kehidupannya sendiri dan gejala kehidupan alam sekitarnya. Dalam ruang lingkup pengembangan akal pikiran inilah, Tuhan mendorong manusia untuk berfikir (Q.S. Fushilat: 53).

b. Mendorong manusia mengamalkan ilmu pengetahuan dan mengaktualisasikan keinginan dan ketaqwaannya dalam hudup seharihari sebagaimana terkandung dalam perintah sholat, puasa, dan sebagainya. Metode yang digunakan Allah dalam hal ini adalah perintah dan larangan serta praktek sebagai halnya Allah memerintahkan shalat dengan menunjukkan manfaatnya (al Ankabut: 45).

c. Mendidik secara berkelompok. Hal ini dapat terlihat dalam sabda Nabi Muhammad saw. yang memerintahkan untuk melaksanakan shalat berjamaah yang memiliki kelebihan pahala (27 kali lipat) dibandingkan 
Priatna, T. (2018, July 9). INOVASI PEMBELAJARAN PAI DI SEKOLAH PADA ERA DISRUPTIVE INNOVATION. Jurnal Tatsqif, 16(1), 16-41. Retrieved from http://journal.uinmataram.ac.id/index.php/tatsqif/article/view/158

dengan yang tidak berjamaah. Demikian pula halnya dengan kewajiban melaksanakan shalat Jum'at bagi setiap muslim.

d. Mendidik secara intruksional yang bersifat kewajiban mengerjakan. Hal tersebut tergambarkan dalam firman Allah yang memerintahkan kewajiban shalat, puasa, zakat dan haji.

e. Mendidik dengan bercerita atau berkisah, yaitu dengan mendeskripsikan peristiwa sejarah yang menyangkut ketaatan atau kemungkaran manusia terhadap perintah-perintah dan laranganlarangan Tuhan (Q.S. Yusuf: 111 Yusuf: 3, al Maidah: 27-28 dan 31, dan lainnya.)

f. Mendidik melalui bimbingan dan penyuluhan (Yunus: 57)

g. Pemberian contoh dan teladan. Allah telah menunjukkan bahwa contoh keteladanan dari kehidupan nabi Muhammad yang mengandung nilai pedagogis bagi manusia (Q.S. al-Ahzaab: 21)

h. Mendidik melalui diskusi. Cara ini juga mendapat perhatian dalam alQur'an. Dengan metode ini pendidikan akan menghantarkan anak didik kepada tingkat pemahaman yang lebih baik. (Q.S. an-Nahl: 125)

i. Mendidik dengan cara tanya jawab. Para Nabi dan Rasul sering menggunakan bentuk ini. Hal ini terlihat pada adanya perintah Allah untuk bertanya kepada orang yang lebih tahu. Bahkan hal itu terlihat pada masa Rasulullah bahwa banyak umatnya yang diperkenankan untuk bertanya kepadanya tentang masalah-masalah yang belum diketahui mereka.

j. Mendidik dengan menggunakan perumpamaan (Q.S. ar-Ra'd: 17)

k. Mendidik secara targhieb dan tarhieb, yaitu memberikan pelajaran dengan dorongan (motivasi) untuk memperoleh kegembiraan dan ancaman mendapat kesusahan jika tidak mengikuti kebenaran. (Q.S. Fushshilat: 46). 
Terdapat beberapa metode pembelajaran yang lazim digunakan untuk mengimplementasikan pembelajaran Pendidikan Agama Islam, diantaranya (Gintings, 2008):

1. Metode Ceramah. Metode ceramah adalah penerangan lisan atas materi pembelajaran kepada sekelompok pendengar untuk mencapai tujuan pembelajaran dalam jumlah yang relatif besar. Seperti ditunjukkan oleh Mc. Leish (1976), melalui ceramah, dapat dicapai beberapa tujuan. Dengan metode ceramah, guru dapat mendorong timbulnya inspirasi bagi pendengarnya. Gage dan Berliner (1981), menyatakan metode ceramah cocok untuk digunakan untuk penyampaian bahan belajar berupa informasi dan bahan belajar yang sukar didapatkan.

2. Metode Diskusi. Diskusi adalah proses pelibatan dua orang atau lebih untuk berinteraksi saling bertukar pendapat, saling mempertahankan pendapat dalam memecahkan masalah. Pembelajaran yang menggunakan metode diskusi bersifat interaktif. Penggunaan metode diskusi dianggap dapat meningkatkan kemampuan anak untuk memahami konsep dan memecahkan masalah.

3. Metode Demonstrasi. Demonstrasi sebagai metode pembelajaran adalah bilamana seorang guru, seorang demonstrator atau seorang siswa memperlihatkan kepada seluruh kelas suatu proses. Kelebihan metode demonstrasi diantaranya adalah perhatian siswa dapat lebih dipusatkan, proses belajar siswa lebih terarah pada materi yang sedang dipelajari; pengalaman dan kesan belajar lebih melekat dalam diri siswa. Adapun kelemahan metode demonstrasi diantaranya adalah siswa kadang kala sukar melihat dengan jelas benda yang diperagakan; Tidak semua benda dapat didemonstrasikan.

4. Metode Ceramah Plus. Ceramah Plus adalah metode pembelajaran yang menggunakan lebih dari satu metode, yakni metode ceramah yang dikombinasikan dengan metode lainnya. Ada tiga macam metode 
ceramah plus, diantaranya yaitu: Metode ceramah dengan tanya jawab dan tugas; dengan diskusi dan tugas; dengan demonstrasi dan latihan, dan sebagainya.

5. Metode Resitasi. Resitasi adalah suatu metode pembelajaran mengharuskan siswa membuat resume dengan pemahaman sendiri. Kelebihan metode ini adalah hasil belajar yang diperoleh peserta didik akan dapat diingat lebih lama; peserta didik dilatih untuk untuk meningkatkan keberanian, inisiatif, tanggung jawab dan kemandirian. Kelemahan resitasi adalah peserta didik kadang kala melakukan penipuan dengan meniru hasil pekerjaan orang lain tanpa mau bersusah payah mengerjakan sendiri; terkadang tugas dikerjakan oleh orang lain tanpa pengawasan; sulit memberikan tugas yang dapat mengidentifikasi perbedaan individual.

6. Metode Eksperimental. Metode eksperimental adalah cara pengelolaan pembelajaran dimana siswa didesain melakukan aktivitas percobaan dengan mengalami dan membuktikan sendiri hal yang dipelajarinya. Siswa diberi kesempatan mengalami dan melakukan sendiri, mengamati suatu obyek, menganalisis, membuktikan dan menarik kesimpulan sendiri tentang obyek yang dipelajarinya.

7. Metode Study Tour (Karya wisata). Metode Study tour (karya wisata) adalah metode mengajar dengan mengajak peserta didik mengunjungi suatu objek guna memperluas pengalaman dan selanjutnya peserta didik membuat laporan dan mendiskusikan serta menuliskan hasil kunjungan tersebut.

8. Metode Latihan Keterampilan. Metode latihan keterampilan (drill method) adalah suatu metode pembelajaran dengan memberikan pelatihan berulang, dan mengajaknya langsung ke tempat latihan keterampilan untuk melihat proses dan manfaat sesuatu. Metode latihan keterampilan ini bertujuan membentuk kebiasaan atau pola yang otomatis pada peserta didik. 
Priatna, T. (2018, July 9). INOVASI PEMBELAJARAN PAI DI SEKOLAH PADA ERA DISRUPTIVE INNOVATION. Jurnal Tatsqif, 16(1), 16-41. Retrieved from http://journal.uinmataram.ac.id/index.php/tatsqif/article/view/158

9. Metode Pemecahan Masalah (problem solving method). Metode pemecahan masalah bukan hanya sekadar metode mengajar, tetapi juga merupakan suatu metode berpikir, sebab dalam problem solving dapat digunakan metode-metode lainnya. Metode ini dimulai dengan mencari data sampai menarik kesimpulan. Metode ini merangsang peserta didik berfikir dan menggunakan wawasan. Seorang guru harus pandai-pandai merangsang siswanya untuk mencoba mengeluarkan pendapatnya. Selain metode-metode tersebut tentunya masih banyak metode yang lainnya.

Sintaks pembelajaran Pendidikan Agama Islam di sekolah/madrasah dapat disesuaikan dengan pilihan, baik model pembelajaran langsung (direct instruction), maupun pembelajaran kooperatif (Cooperative learning). Sintaks model pembelajaran langsung (direct instruction) secara umum adalah: 1) Orientasi tujuan pembelajaran; 2) Mereview pengetahuan dan keterampilan prasyarat; 3) Menyampaikan materi pelajaran; 4) Melaksanakan bimbingan dan memberikan kesempatan kepada siswa untuk beraktivitas; 5) Menilai kinerja siswa dan memberikan umpan balik. Sedangkan sintaks/prosedur model kooperatif secara umum menggunakan prosedur: 1) Penjelasan materi, 2) aktivitas/Belajar dalam kelompok; 3) Penilaian; dan 4) Pengakuan dan apresiasi terhadap kelompok.

Berkenaan dengan karakteristik mata pelajaran PAI, dapat diidentifikasi beberapa pokok pikiran, yaitu:

1. Pendidikan Agama Islam merupakan mata pelajaran yang dikembangkan dari materi pokok agama Islam (al- Qur'an dan Hadis, aqidah, akhlak, fiqih dan sejarah peradaban Islam);

2. Ditinjau dari segi muatan pendidikannya, Pendidikan Agama Islam merupakan mata pelajaran pokok yang menjadi satu komponen yang tidak dapat dipisahkan dengan mata pelajaran lain yang bertujuan untuk pengembangan sikap, moral dan kepribadian peserta didik. 
Priatna, T. (2018, July 9). INOVASI PEMBELAJARAN PAI DI SEKOLAH PADA ERA DISRUPTIVE INNOVATION. Jurnal Tatsqif, 16(1), 16-41. Retrieved from http://journal.uinmataram.ac.id/index.php/tatsqif/article/view/158

Semua mata pelajaran yang memiliki tujuan tersebut harus seiring dan sejalan dengan tujuan yang ingin dicapai oleh mata pelajaran PAI;

3. Diberikannya mata pelajaran Pendidikan Agama Islam bertujuan untuk terbentuknya peserta didik yang beriman dan bertakwa kepada Allah Swt., berbudi pekerti yang luhur dan berakhlak yang mulia, dan memiliki pengetahuan yang memadai tentang Islam.

4. Pendidikan Agama Islam adalah mata pelajaran yang tidak hanya mengantarkan peserta didik dapat menguasai berbagai kajian keislaman, tetapi pembelajaran PAI lebih menekankan bagaimana peserta didik mampu menguasai kajian keislaman tersebut sekaligus dapat mengamalkannya dalam kehidupan sehari-hari. Dengan demikian, Pendidikan Agama Islam tidak hanya menekankan pada aspek kognitif saja, tetapi juga aspek afektif dan psikomotornya.

5. Tujuan akhir dari mata pelajaran Pendidikan Agama Islam adalah terbentuknya peserta didik yang memiliki akhlak yang mulia, yang merupakan misi utama diutusnya Nabi Muhammad SAW di dunia. Pendidikan Islam memerhatikan segi-segi pendidikan akhlak (Mendikbud. 2014).

\section{TANTANGAN DAN INOVASI PEMBELAJARAN PAI DI ERA DISRUPSI}

Abad 21 telah memperlihatkan karakternya yang global, terbuka dan nyaris tanpa batas. Global karena abad 21 menandai dirinya dengan interaksi dan komunikasi yang melewati batas-batas konvensional dan batas geografis. Terbuka karena abad 21 menyuguhkan semua fakta, berita dan informasi menjadi terbuka untuk diterima, dikurasi dan dipublikasikan oleh siapapun. Wilayah privasi dan emosional tidak mendapat tempat memadai di abad 21, karena batas psikologis, ideologi dan keyakinan mencair hampa tanpa fungsi. Hal demikian semata karena di abad 21 ini, peran dan determinasinya teknologi informasi dan komunikasi sangat superior. 
Priatna, T. (2018, July 9). INOVASI PEMBELAJARAN PAI DI SEKOLAH PADA ERA DISRUPTIVE INNOVATION. Jurnal Tatsqif, 16(1), 16-41. Retrieved from http://journal.uinmataram.ac.id/index.php/tatsqif/article/view/158

Era teknologi informasi dan komunikasi di abad 21 dengan sangat jelas menghadirkan ciri-ciri sebagai berikut: (1) Daya muat untuk mengumpulkan, menyimpan, memanipulasikan, dan menyajikan informasi berkembang pesat; (2) Kecepatan penyajian informasi sangat meningkat; (3) Keragaman pilihan informasi tersedia begitu banyak; (4) biaya perolehan informasi menjadi murah dan bias instan; (5) Distribusi informasi yang semakin cepat dan menjadi luas jangkauannya. Kemajuan teknologi informasi dan komunikasi telah mengakibatkan disrupsi yang tak terduga, termasuk terhadap dunia pendidikan.

Perkembangan teknologi informasi dan komunikasi senyatanya telah memberikan sumbangan signifikan dan mendorong terjadinya perubahan dalam dunia pendidikan maupun pembelajaran. Guru bukan lagi satu-satunya sumber dalam proses pembelajaran. Eric Ashby (1967) menulis tentang perkembangan ini dalam empat revolusi dramatis. Revolusi pertama terjadi pada saat masyarakat memberikan wewenang dan kepercayaan pendidikan kepada orang tertentu saja hingga timbul "profesi guru". Revolusi kedua terjadi saat digunakannya tulisan sebagai sumber belajar di sekolah melalui "buku pelajaran". Revolusi ketiga terjadi saat ditemukannya mesin cetak yang mengakibatkan pendidikan lebih berbasis pada sumber buku yang beragam dan marak tersedia”. Revolusi keempat terjadi saat teknologi komunikasi berkembang sangat pesat dimana semua bahan, proses dan bentuk pendidikan dapat ditransfer lewat teknologi.

Lalu apa yang bisa dilakukan oleh sekolah, pendidikan dan pembelajaran menghadapi trend zaman seperti itu? Sebuah studi berjudul "Digital Citizenship Safety among Children and Adolescents in Indonesia" yang diselenggarakan oleh Kementerian Kominfo, Kementerian PPPA bersama UNICEF dalam salah satu poin rekomendasinya menyatakan:

Pihak orang tua dan guru harus langsung terlibat memberikan pengawasan dan pendampingan bagi anak-anak mereka dalam aktivitas digitalnya. 
Orang tua seyogyanya menjadi 'teman' di jejaring sosial anak, karena di sinilah anak-anak dan remaja berselancar di dunia maya. Orang tua dapat bergabung dan berkomunikasi secara intensif dengan anak- anak untuk menciptakan lingkungan yang aman dan positif bagi pertumbuhan dan perkembangan anak-anak mereka di dunia cyber.

Perkembangan teknologi informasi dan komunikasi telah membawa revolusi dalam berbagai bidang kehidupan, dan dunia pendidikan. Pendidikan merupakan faktor kunci dalam peningkatan kualitas sumber daya manusia. Pengembangan dan implementasi kurikulum saat ini yang mengintegrasikan teknologi informasi dalam pembelajaran mengharuskan guru dan peserta didik menguasai teknologi. Peserta didik dan guru aktif terlibat dalam proses belajar dengan memanfaatkan teknologi, baik sebagai sumber, media maupun sebagai alat pembelajaran. Paradigma pembelajaran telah bergeser menuju pembelajaran berbasis digital. Model pembelajaran berkembang dalam bentuk pembelajaran elektronik ( $e$ learning), buku elektronik (e-book), kelas online, diskusi online, pembelajaran berbasis komputer. Penggunaan papan tulis dan spidol, berganti dengan penggunaan media Notebook, LCD Projector dan sebagainya. Printed material buku sumber, modul dan lembar kerja siswa berganti dengan e-book, digital library, YouTube dan laman-laman internet. Pembelajaran konvensional ceramah di depan kelas berganti dengan berbagai model pembelajaran berbasis IT seperti CBT (Computer Based Test), CBI (Computer Based Instruction), Distance Learning, LCC (Learner-Centered Classroom), Teleconference dan sebagainya dengan memanfaatkan fasilitas seperti e-mail (surat elektronik), mobile phone, MP3 player, website, blogging, search engine dan lain-lain..

Keterampilan dalam penguasaan teknologi merupakan kecakapan hidup (life skill) yang harus dimiliki oleh guru dan peserta didik. Jika tidak, peserta didik akan mengalami kesulitan bersaing. Peran seorang guru sangat krusial dan signifikan dalam hal ini, untuk itu guru juga harus membekali diri dengan penguasaan teknologi informasi. Siswa yang cakap 
dan terampil tentunya dihasilkan oleh para pendidik yang juga harus terampil dan selalu meningkatkan kompetensinya.

Peserta didik secara intensif harus dibekali keterampilan dasar menghadapi abadi 21 ini. Keterampilan-keterampilan tersebut meliputi yaitu: (1) Critical thinking and problem solving (Berpikir kritis dan pemecahan masalah); (2) Collaboration and communication (Kolaborasi dan komunikasi); (3) Creativity and imagination (Kreativitas dan imajinasi); (4) Citizenship (Kewarganegaraan); (5) Digital literacy (melek digital); dan yang paling utama adalah (6) Student leadership and personal development (kepemimpinan siswa dan pembangunan diri).

Pada pihak lain, guru juga harus melengkapi dirinya dengan kemampuan menjalankan proses pembelajaran yang mampu menjadikan peserta didiknya menguasai core skills atau keterampilan abad 21 tersebut. Prinsip yang harus dipegang oleh pendidik pada era disruptive adalah :

1. Push Beyond Comfort Zone (Keluar dari zona nyaman)

2. Works Toward Well Defined, Specific Goals (Bekerja dengan target yang jelas)

3. Focus Intently on Impactful Activities (Fokus memberikan aktivitas yang bermakna dan berdampak)

4. Receive and Respond High Quality Impact (Menerima dan memberikan feedback berkualitas)

5. Develop Mental Model of Expertise (Membentuk mental model seorang expert)

Lalu bagaimana dengan keberadaan pendidikan dan atau pembelajaran Pendidikan Agama Islam menghadapi kecenderungan tersebut. Sementara pada saat yang sama banyak fenomena yang dapat diamati dari pembelajaran PAI saat ini. Pembelajaran Pendidikan Agama Islam di sekolah/madrasah terkesan masih belum memberikan pemahaman yang mendalam dan mamadai tentang nilai-nilai Islam. Metode pembelajaran masih dikembangkan dengan berorientasi pada tradisi 
Priatna, T. (2018, July 9). INOVASI PEMBELAJARAN PAI DI SEKOLAH PADA ERA DISRUPTIVE INNOVATION. Jurnal Tatsqif, 16(1), 16-41. Retrieved from http://journal.uinmataram.ac.id/index.php/tatsqif/article/view/158

menghapal teks-teks dan narasi, sehingga pembelajaran PAI seolah kehilangan kontekstualisasinya dengan realitas sosial. Sarana penunjang pembelajaran PAI terbatas dan masih konvensional.

Pesatnya perkembangan teknologi informasi membuat pembelajaran PAI pada sekolah justru terkesan tertinggal dengan mata pelajaran dan disiplin ilmu lain. Implementasisi kurikulum pendidikan agama Islam belum dilaksanakan secara menyeluruh pada semua cakupan kurikuler. Sekolah masih terpaku pada pembelajaran intra dengan alokasi waktu hanya 2 (dua) jam pelajaran. Pengembangan pembelajaran Pendidikan Agama Islam di luar kelas belum memberikan warna apalagi pengaruh yang signifikan terhadap tatanan komunitas sekolah.

Pembelajaran Pendidikan Agama Islam di sekolah ternyata hanyalah bagian kecil dari materi-materi ke-Islaman yang ada. Dalam perkembangannya kita dapat ketahui bahwasanya pembelajaran Pendidikan Agama Islam di sekolah terbatas diajarkan selama 2 jam untuk satu minggu. Dengan waktu yang sangat singkat tersebut menjadikan pembelajaran Pendidikan Agama Islam di sekolah kehilangan kesempatan untuk mendalami materi secara mendalam. Selain waktu yang sedikit, pembelajaran pendidikan agama Islam di sekolah juga lebih cenderung diajarkan berdasarkan kepada teks-teks atau buku-buku yang menjadi pegangan siswa dalam setiap belajar. Hal ini jelas memberikan kekhawatiran kepada siswa yang hanya belajar dengan materi-materi yang berada dalam buku paket tersebut. Pembelajaran pendidikan agama Islam di sekolah terbatas pada pembelajaran yang bersifat tekstual dengan teknik pembelajaran monton dan kurang variasi. Hal ini terbukti ketika pembelajaran di kelas, guru yang lebih aktif dibandingkan siswa. Selain itu, penggunaan bahan dan sumber belajar siswa pada pembelajaran Pendidikan Agama Islam di sekolah yang masih minim.

Meresponi fenomena tersebut apalagi dalam kaitanya dengan hiruk pikuk perkembangan teknologi informasi, banyak hal yang harus 
Priatna, T. (2018, July 9). INOVASI PEMBELAJARAN PAI DI SEKOLAH PADA ERA DISRUPTIVE INNOVATION. Jurnal Tatsqif, 16(1), 16-41. Retrieved from http://journal.uinmataram.ac.id/index.php/tatsqif/article/view/158

dikembangkan untuk mengoptimalasi pembelajaran PAI di sekolah/madarah. Penulis mengidentifikasi beberapa hal yang dapat dan harus dilakukan.

Pertama, perubahan orientasi pembelajaran PAI. Belajar bukan hanya sekedar mengumpulkan pengetahuan. Belajar adalah proses mental yang terjadi dalam diri seseorang, sehingga menyebabkan munculnya perubahan perilaku. Aktifitas mental itu terjadi karena adanya interaksi individu dengan lingkungan yang disadari. Dewasa ini pembelajaran Pendidikan Agama Islam di sekolah masih dianggap kurang berhasil dalam menggarap sikap dan prilaku keberagamaan peserta didik. Beberapa ahli sering kali menggunakan terminologi 'quo vadis' sebagai suatu ekspresi kekecewaan, keresahan, dan atau kekhawatirannya atas fenomena demikian. Pembelajaran Pendidikan Agama Islam masih nampak seperti sebagai sebuah "bank" (banking concept of education) dimana peserta didik diberikan ilmu pengetahuan agama. Guru seperti subjek aktif, sedang anak didik layaknya objek pasif yang penurut, dan diperlakukan tidak berbeda atau menjadi bagian dari realitas dunia yang "tidak berkesadaran".

Pembelajaran PAI di sekolah dianggap kurang bisa mengubah pengetahuan agama yang kognitif menjadi bermakna dan bernilai yang perlu diinternalisasikan dalam diri peserta didik. Pendidikan Agama Islam belum memiliki relevansi memadai dengan realitas dan perubahan sosial, sehingga peserta didik kurang menghayati nilai-nilai agama. Diperlukan perubahan paradigma pembelajaran PAI yang bukan hanya terbatas pada orientasi kognitif semata, tapi juga ranah psikomotor, afeksi dan yang paling mendesak adalah aspek sikap dan prilaku keberagamaan.

Kedua, pengembangan alternatif pembelajaran PAI. Pengembangan model pembelajaran PAI harus diintegrasikan dengan keseluruhan sistem pendidikan. Seoptimal apapun pembelajaran PAI dengan hanya mengandalkan jam pelajaran di dalam kelas, keberhasilannya akan 
Priatna, T. (2018, July 9). INOVASI PEMBELAJARAN PAI DI SEKOLAH PADA ERA DISRUPTIVE INNOVATION. Jurnal Tatsqif, 16(1), 16-41. Retrieved from http://journal.uinmataram.ac.id/index.php/tatsqif/article/view/158

menyisakan ruang kosong, terutama pada sasaran pembelajaran PAI aspek sikap dan tingkah laku.

Disadari atau tidak, dewasa ini telah lahir sebuah generasi yang berbeda dengan generasi-generasi sebelumnya. Mereka adalah generasi milenial $^{1}$ yang memproklamirkan diri sebagai Connected Generation: Generasi highly-mobile yang selalu terhubung secara online. Data dari www.socialmediatoday.com menyebutkan bahwa November 2016, 68\% generasi milenial mengakses Facebook; dalam satu menit menghasilkan 4.166.669 like, 136 ribu foto dan 293.000 status. Instagram dalam satu menit menghasilkan 2.430.555 like, 43.470 foto dan 28.194 postingan. Twitter dalam satu menit menghasilkan 2.430 .555 cuitan. Mereka milenialis begitu massif dan intensif menerima serta berbagi informasi melalui jejaring sosial kapanpun dan dimanapun. Mereka merupakan selflearner yang senyap mencari sendiri pengetahuan yang mereka butuhkan melalui 'sang guru' mbah Google dan 'buku babon pelajaran' Wikipedia. Mereka adalah generasi melek visual (visually literate) dan melek data (data literate). Mereka generasi milenial tersebut adalah anak-anak kita siswa siswi SMA, SMP, bahkan yang lebih muda lagi.

Kehadiran sosial media memang memberikan banyak manfaat, tak hanya menjadi media untuk berkomunikasi namun juga menjadi sarana untuk mendapatkan beragam informasi-informasi terbaru dan terupdate. Hanya saja keuntungan-keuntungan tersebut juga sejalan dengan dampak negatif yang diberikan sosial media. Fungsi sosial media bagi siswa siswi kita beragam, diantaranya adalah dijadikan sebagai media untuk mengungkapkan diri yang lebih baik, membantu remaja

${ }^{1}$ Milenial (juga dikenal sebagai Generasi Y) adalah kelompok demografi setelah Generasi $\mathrm{X}$ (Gen-X). Tidak ada batas waktu yang pasti untuk awal dan akhir kelompok ini. Biasanya menggunakan awal 1980-an sebagai awal kelahiran dan pertengahan tahun 1990-an hingga awal 2000-an sebagai akhir kelahiran. Milenial terkadang disebut sebagai "Echo Boomers" karena adanya 'booming' (peningkatan besar) tingkat kelahiran di tahun 1980-an dan 1990-an. Karakteristik Milenial beragam berdasarkan wilayah dan kondisi sosial-ekonomi. Namun, generasi ini umumnya ditandai oleh peningkatan penggunaan dan keakraban dengan komunikasi, media, dan teknologi digital. 
Priatna, T. (2018, July 9). INOVASI PEMBELAJARAN PAI DI SEKOLAH PADA ERA DISRUPTIVE INNOVATION. Jurnal Tatsqif, 16(1), 16-41. Retrieved from http://journal.uinmataram.ac.id/index.php/tatsqif/article/view/158

menemukan identitas, membangun relationship dan cultural awareness, berpotensi menimbulkan sifat iri hati, memicu rasa cemas, hilangnya privasi, munculnya budaya cyber-bullying, mempengaruhi kualitas tidur, dan mempengaruhi kesehatan mental.

Laman jejaring sosial kini tidak hanya merevolusi cara kita berinteraksi dengan sesama. Namun juga memungkinkan untuk memberikan pengalaman lainnya di dunia maya. Jika biasanya social platform ini digunakan hanya diwaktu senggang, kini para siswa mulai beralih ke jaringan sosial untuk memberikan pengalaman baru dalam kegiatan belajar mengajar. Dilansir dari huffingtonpost, paling tidak terdapat tujuh cara siswa manfaatkan platform media sosial saat ini, yaitu: Tugas kelompok melalui facebook, konverensi video kelas melalui google hangout, the flipped classroom, jaringan industry mellaui linkedin, Q \& A memlalui twiiter/reddit, penelitian dan debat melalui Quora, pengembangan seni dan kerajian tangan melalui pinterest.

Pada pihak lain, penyalagunaan media sosial juga semakin memprihatinkan. Banyak fakta menggambarkan bagaimana prilaku dan aktivitas anak-anak kita di sosial media, diantaranya upload foto yang tidak pantas dan tidak senonoh, berbagi foto korban kecelakaan, korban perang dan kekerasan, foto anak kecil melakukan hal yang tak pantas seperti merokok, mengumpat dengan kata-kata kasar untuk meluapkan amarah, membully di media sosial, atas nama eksis di media sosial dengan merusak alam, pencemaran nama baik, dana lain sebagainya.

Fenomena tersebut sudah saatnya dipikirkan serius untuk diantisapasi dan dilawan dengan tidak sekedar himbauan. Dunia pendidikan perlu mengambil peran aktif. Tidak ada yang salah dengan kemajuan teknologi. Yang perlu kita lakukan adalah memanfaatkannya untuk sesuatu yang positif. Penggunaan media sosial dalam pembelajaran harus menjadi alternatif. Termasuk digunakan dan dimanfaatkannya media sosial untuk pengembangan pembelajaran PAI di sekolah/madrasah. 
Priatna, T. (2018, July 9). INOVASI PEMBELAJARAN PAI DI SEKOLAH PADA ERA DISRUPTIVE INNOVATION. Jurnal Tatsqif, 16(1), 16-41. Retrieved from http://journal.uinmataram.ac.id/index.php/tatsqif/article/view/158

Pembelajaran PAI di sekolah/madrasah harus dikembangkan dan diinovasi sedemikian rupa, sehingga pembelajaran PAI menjadi up to date dan menarik minat para siswa. Penggunaan teknologi informasi dalam model pembelajaran PAI harus terus dikembangkan dan harus ditempatkan sebagai sumber bahan ajar, referensi belajar, dan sumber informasi yang beragam bagi para siswa dan guru. Guru (guru PAI) dan orang tua harus diskenariokan terhubung dalam media sosial dengan para siswa, Sehingga apapun aktiviats siswa di sosial media terawasi dan terhubung dengan guru dan orang tua. Demikian pula sebaliknya, aktivitas guru dan orang tua di sosial media terhubung dengan siswa, sehingga dapat menjadi bagian dari row model pendisiplinan dan pengasuhan pembelajaran PAI.

Group dan komunitas media sosial harus dibangun bersama secara interaktif-multi arah antara guru dan siswa bahkan dengan orang tua. Group media sosial diberdayakan dan difungsikan sebagai virtual class yang memungkinkan semua berinteraksi secara imejiner. Guru PAI tidak terpaku pada 2 jam pelajaran di sekolah, tapi setiap waktu, kapanpun dan dimanapun dapat melakukan refreshment, penguatan dan penambahan wawasan pada peserta didik. Laman internet yang berhubungan dengan sumber pembelajaran memungkin-kan materi pembelajaran disajikan lebih variatif dan menarik. Ketersediaan Al Qur'an digital, kitab -kitab hadits digital, kitab - kitab tafsir digital dan berbagai sumber khazanah Islam, sangatlah disayangkan jika para guru PAI tidak menjadikannya sebagai media pembelajaran.

Pada awal perkembangnya sekolah mengajarkan kompetensi inti yaitu (3M) membaca, menulis dan menghitung. Padahal kecerdasan anakanak kita telah lama melampaui batas itu. Kebutuhan anak sekolah lebih dari sekedar kompetensi inti tersebut. Sekolah harus mulai membelajarkan anak-anak kita bagaimana cara belajar, diberikan pendidikan yang relevan, dilatih hidup mandiri, berfikir kritis, dorong untuk menjelajahi profesiprofesi baru di masa depan, kemampuan untuk beradaptasi terhadap 
perubahan dan yang terpenting ajarkan sesuatu yang tidak bisa dilakukan oleh teknologi, seperti berfikir kreatif, inovatif, kerja sama tim dan terkait budaya. Guru dan orang tua harus menekankan pentingnya pendidikan karakter dan soft skill agar kelak anak-anak kita mampu menjadi pribadi yang mandiri dan mempunyai kehidupan yang lebih baik. Guru memegang peranan kunci mengarahkan mengfasilitasi dan mendampingi peserta didik belajar sendiri. Teknologi informasi harus dimanfaatkan guru untuk membantu peran tersebut. George Couros mengemukakan "technology will never replace great teachers but technology in the hands of great teachers is transformational"2.

\section{KESIMPULAN}

Berdasarkan kajian dapat disampaikan beberapa simpulan sebagai berikut:

1. Disruptive innovation merupakan fenomea perkembangan dunia saat memasuki era revolusi industri 4.0, yang ditandai dengan masifnya perkembangan digital technology, artificial intelligence, big data, robotic, dan perubahan yang begitu cepat dimana banyak sekali inovasi, tidak disadari oleh organisasi mapan tapi sangat dirasakan mengganggu jalannya aktivitas tatanan sistem lama atau bahkan menghancurkan sistem lama tersebut.

2. Model pembelajaran adalah kerangka konseptual yang menggambarkan prosedur sistematis dalam mengorganisasikan pengalaman untuk mencapai tujuan belajar. Model pembelajaran terbentuk dari unsur fokus, sintaks, sistem sosial dan situasi pembelajaran, serta factor pendukung.

3. Pembelajaran PAI merupakan upaya mendorong peserta didik untuk mempelajari kurikulum PAI yang mengakibatkan perubahan tetap dalam

2 https://georgecouros.ca/blog/archives/tag/c-s-lewis C.S. Lewis, $\underline{5 \text { Thoughts to }}$ Push Learning. 
Priatna, T. (2018, July 9). INOVASI PEMBELAJARAN PAI DI SEKOLAH PADA ERA DISRUPTIVE INNOVATION. Jurnal Tatsqif, 16(1), 16-41. Retrieved from http://journal.uinmataram.ac.id/index.php/tatsqif/article/view/158

tingkah laku peserta didik. Pembelajaran PAI merupakan upaya memfasilitas peserta didik belajar terus menerus pada semua aspek, baik kognitif, afektif dan psikomotorik.

4. Banyak hal yang harus dikembangkan untuk mengoptimalisasi pembelajaran PAI di sekolah/madarah mengahdapi Disruptive innovation yang didorong oleh perkembangan teknologi informasi, diantaranya adalah Pertama, perubahan orientasi pembelajaran PAI. Pembelajaran PAI di sekolah dianggap kurang bisa mengubah pengetahuan agama yang kognitif menjadi bermakna dan bernilai yang perlu diinternalisasikan dalam diri peserta didik. Diperlukan perubahan paradigma pembelajaran PAI yang bukan hanya terbatas pada orientasi kognitif semata, tapi juga ranah psikomotor, afeksi dan yang paling mendesak saat ini adalah aspek sikap dan prilaku keberagamaan. Kedua, Pengembangan alternatif pembelajaran PAI. Pengembangan model pembelajaran PAI harus diintegrasikan dengan keseluruhan sistem pendidikan. Pembelajaran PAI di sekolah/madrasah harus dikembangkan dan diinovasi sedemikian rupa, sehingga pembelajaran PAI menjadi up to date dan menarik minat para siswa. Penggunaan teknologi informasi dalam model pembelajaran PAI harus terus dikembangkan dan harus ditempatkan sebagai sumber bahan ajar, referensi belajar, dan sumber informasi. Penggunaan media sosial dalam pembelajaran juga harus menjadi alternatif. Termasuk digunakan dan dimanfaatkannya media sosial untuk pengembangan pembelajaran PAI di sekolah/madrasah.

\section{DAFTAR PUSTAKA}

Abdul Azis Wahab. Metode dan Model-Model Mengajar Ilmu Pengetahuan Sosial. (Bandung: Alfabeta, 2007)

Abdul Majid, Belajar dan Pembelajaran Pendidikan Agama Islam, (Bandung, Remaja Rosdakarya, 2012)

Abdurakhman Gintings, Esensi Praktis Belajar dan Pembelajaran, (Bandung, Humaniora, 2008) 
Priatna, T. (2018, July 9). INOVASI PEMBELAJARAN PAI DI SEKOLAH PADA ERA DISRUPTIVE INNOVATION. Jurnal Tatsqif, 16(1), 16-41. Retrieved from http://journal.uinmataram.ac.id/index.php/tatsqif/article/view/158

Amir. T. M. Inovasi pendidikan Melalui Problem Based Learning Bagaimana pendidik Memberdayakan Pembelajar di Era Pengetahuan (Jakarta, Kencana, 2009)

Bruce Joyce, Marsha Weil \& Emily Calhoun, Model of Teaching. (New Jersey, Pearson Education. Inc., 2011), Model of Teaching, Model-Model Pengajaran, terj.Achmad Fawaid, (Yogyakarta. Pustaka Pelajar.2009)

Eti Jaskati. Dasar-Dasar Model Pembelajaran. (Jakarta: Departemen Pendidikan Nasional, 2015)

J.J. Hasibuan \& Moedjiono, Proses Belajar Mengajar, (Bandung, Remadja Karya,1986)

M. D. Dahlan, Model-Model Mengajar, Beberapa Alternatif Interaksi Beiajar Mengajar, (Bandung : Diponegoro, 1990)

Muhaimin, Paradigma Pendidikan Islam, (Bandung, Remaja Rosdakarya, 2004)

Oemar Hamalik, Kurikulum Dan Pembelajaran, (Jakarta: Bumi Aksara, 2011)

Trianto, Mendesain Model Pembelajaran Inovatif-Progresif: Konsep, Landasan, dan Implementasinya pada Kurikulum Tingkat Satuan Pendidikan, (Jakarta, Kencana Predana Media Group, 2012). 